\title{
Peran Guru dalam Pembelajaran Resolusi Konflik Berbasis Nilai Budaya Pela di Kota Ambon
}

\author{
Samuel Patra Ritiauw \\ Universitas Pattimura \\ e-mail: pritiauw@gmail.com
}

\begin{abstract}
This study was conducted to construct the teacher's role in learning the conflict resolution based on the cultural value of Pela in social studies learning for junior high school students in Ambon City. Research is carried out through the application of the Research and Development method as developed by Borg and Gall, so that teachers can develop roles in learning conflict resolution well. The results showed that the teacher has a role that cannot be replaced by any media. This can be seen from the six roles of the teacher, namely the teacher as an educator, expert, supervisor, manager, mediator, and evaluator. The six roles must be possessed by social studies teachers to carry out learning of conflict resolution based on Pela cultural values in order to produce peaceful classes.
\end{abstract}

Keywords: Conflict Resolution Education, Social Studies Learning, Pela Culture Value.

\begin{abstract}
Abstrak
Penelitian ini dilakukan untuk mengkonstruksi peran guru dalam pembelajaran resolusi konflik berbasis nilai budaya Pela dalam pembelajaran Ilmu Pengetahuan Sosial pada siswa Sekolah Menengah Pertama di Kota Ambon. Penelitian dilakukan melalui penerapan metode Research and Development sebagaimana yang dikembangkan oleh Borg and Gall, sehingga guru dapat mengembangkan peran dalam pembelajaran resolusi konflik dengan baik. Hasil penelitian menunjukkan bahwa guru memiliki peran yang tidak bisa digantikan oleh media apapun. Hal ini terlihat dari enam peran guru, yakni guru sebagai pendidik, expert, pembimbing, manager, mediator, dan evaluator. Keenam peran tersebut harus dimiliki oleh guru Ilmu Pengetahuan Sosial guna melaksanakan pembelajaran resolusi konflik berbasis nilai budaya pela guna menghasilkan kelas yang damai.
\end{abstract}

Kata Kunci: Pendidikan Resolusi Konflik, Pembelajaran Ilmu Pengetahguan Sosial, Nilai Budaya Pela. 


\section{PENDAHULUAN}

Pendidikan merupakan wahana yang sangat strategis dalam meningkatkan kualitas sumber daya manusia serta merupakan faktor determinan pembangunan. Oleh karena itu, maka pendidikan merupakan usaha sadar untuk menyiapkan peserta didik melalui kegiatan bimbingan, pengajaran, dan atau latihan bagi peranannya di masa yang akan datang. Pendidikan juga harus dilakukan oleh orangorang yang sadar dalam membangun generasi bangsa (Ball and Forzan, 2010: 498). Dengan demikian, maka pendidikan adalah "sebuah proses" untuk membawa manusia dari kondisi apa adanya kepada kondisi seharusnya" (Kartadinata, 2012: 3). Jika kita hubungkan pengertian pendidikan dari para ahli di atas dengan Pendidikan Ilmu Pengetahuan Sosial, maka idealnya Pendidikan Ilmu Pengetahuan Sosial harus mampu membawa atau mengatar siswa dari kondisi apa adanya (dengan sejumlah potensi konflik yang berkembang di dalam diri siswa) kepada kondisi bagaimana seharusnya siswa itu ada (mampu mengelola potensi konflik dan menyelesaikan konflik secara konstruktif) (Ahrari, at all. 2013: 1-8; Ritiauw, 2017: 357-368). Salah satu cara yang bisa dilakukan untuk membelajarkan siswa adalah dengan penerapan Pembelajaran Resolusi Konflik. Konflik merupakan masalah sosial yang bisa terjadi kapan dan di mana saja, terutama dalam aktivitas keseharian siswa (Fisher,et.al, 2001; Jones, 2015: 13; Garner, 2008: 23). Akhir-akhir ini bentuk konflik di sekolah atau lembaga pendidikan kerap terjadi, baik yang disebabkan oleh proses belajarmengajar yang tidak sehat maupun karena rapuhnya sistem manajemen sekolah.

Untuk menjembatani maraknya fenomena konflik tersebut, maka guru mestinya dapat menghadirikan pembelajaran yang berpihak pada peserta didik melalui pengembangan aspek pengetahuan, sikap dan keterampilan. Jones dan Campton (Jones, 2004: 233) menyatakan bahwa pendidikan resolusi konflik merupakan: "Provides critical life skills necessary for building caring communities and establishing constructive relationships." Dengan pendidikan resolusi konflik diharapkan siswa dapat memahami konflik dengan lebih baik, mampu mengendalikan emosi, dan mempunyai keterampilan untuk memecahkan konflik secara konstruktif. Sementara, Crawford and Bodine (1994a) menyatakan bahwa "Conflict resolution offers an alternative approach that brings the parties of the dispute together, provides them with the skills to resolve the dispute, and expects them to do so. In the conflict resolution process, those with ownership of the problem participate directly in crafting a solution". Dengan mempelajari resolusi konflik, peserta didik dipersiapkan untuk memiliki keterampilan menyelesaikan konflik serta dapat berkontribusi dalam menyelesaikan konflik yang berkembang dalam masyarakat. Untuk membantu siswa sampai pada tahapan tersebut, maka peran guru sebagai agen perubahan sangatlah diharapkan. Scriven (1994: 151; Garner, 2008: 15) menjelaskan bahwa guru adalah salah satu faktor yang sangat penting dalam menentukan kualitas pembelajaran IPS di kelas yang pada akhirnya berdampak pada peningkatan demokrasi dan terwujudnya pembelajaran yang damai, (Ahrari, at all. 2013: 1-8).

Sukmadinata, (2004b) mengemukakan bahwa guru memegang peranan yang cukup penting baik dalam perencanaan maupun pelaksanaan kurikulum. Lebih lanjut dikemukakan bahwa guru adalah perencana, pelaksana dan pengembang kurikulum bagi kelasnya, Walid (2010: 1) guru adalah contoh, Mulyasa (2008: 48) guru harus menjadi suri teladan, Scriven (1994: 151) guru harus menginspirasi siswa dan masyarakat, karena guru adalah manusia yang bertanggung jawab (Hamalik, 2008: 39), yang tidak kalah penting bahwa guru adalah aktor kunci dalam menghitamputihkan nasib generasi suatu bangsa. Dengan demikian, sukses tidaknya suatu pembelajaran ditentukan oleh kualitas guru sebagai aktor kunci (Ritiauw, 2018). Untuk mengukur kualitas guru setidaknya dapat ditinjau dari dua aspek yaitu dari aspek proses dan aspek hasil. Dari aspek proses guru dikatakan berhasil apabila mampu melibatkan sebagian besar peserta didik secara aktif baik fisik, mental maupun sosial dalam proses pembelajaran, (Ahrari, at all. 2013: 1-8). Aspek hasil, guru dikatakan berhasil apabila pembelajarnya yang diberikannya mampu memperbaiki mental perilaku peserta didik ke arah penguasaan kompetensi, sikap, keteram- 
pilan dan pengetahuan (Maftuh, 2010; Sapriya, 2012).

Untuk menjembatani masalah tersebut, jones (2015) menjelaskan bahwa guru harus berperan aktif dalam merancang dan mengembangkan pembelajaran. Salah satu langkah yang dilakukan yakni mengawali pembelajaran dimulai dengan mengemukakan masalah atau konflik yang terjadi dan mengajak siswa untuk terlibat secara aktif dalam membangun pembelajaran yang berbasis pada resolusi konflik. Dalam membangun model ini, Jones (2015: 13) mengemukakan tiga lagkah yang harus diperankan guru yakni: (1) attitude assurance, guru harus memastikan apakah siswa memiliki sikap dan pandangan yang benar tentang konflik, (2) cooperation coaching, memberikan kesempatan kepada siswa untuk berlatih, praktek dengan siswa yang lain dalam menyelesaikan konflik, dan (3) negotiation, mengajarkan siswa bagaimana melakukan negosiasi yang benar dalam menyelesaikan konflik.

Namun dalam kenyataan di lapangan menunjukkan bahwa peran guru dalam pembelajaran, khususnya Pendidikan Ilmu Pengetahuan Sosial di sekolah masih jauh dari harapan. Proses pembelajaran di kelas hampir tidak mampu membawa siswa sampai pada level bagaimana seharusnya siswa tersebut untuk hidup dan berkembang di tengah-tengah masyarakat. Dalam hal ini siswa belum mampu berperan sebagai anggota masyarakat, yang turut memberikan kontribusi bagi penyelesaian beragam konflik yang berkembang. Kondisi tersebut terjadi sebagai akibat dari lemahnya Pendidikan Ilmu Pengetahuan Sosial yang berfungsi sebagai alat pewarisan nilai-nilai sosial. Nilai-nilai sosial yang berkembang dalam kehidupan masyarakat tidaklah dijadikan sebagai sumber pembelajaran di kelas (Welton, 1987; Muchtar, 2004: 220). Hal ini disebabkan karena proses Pendidikan Ilmu Pengetahuan Sosial di kelas lebih mengutamakan hafalan dan siswa dianggap sebagai "mesin foto kopi" yang harus menghafal isi buku paket dan mengerjakan Lembar Kerja Siswa yang telah tersedia pada buku pegangan siswa, (Hasan, 2012: 20; Somantri, 2001: 39). Hal menarik lainnya dikemukakan oleh Jones (2015), bahwa masalah terbesar guru adalah mereka tidak memiliki waktu untuk melatih siswa menghadapi konflik.

Realita di atas menunjukan bahwa guru dengan sengaja membiarkan siswa berkembang berdasarkan potensinya masing-masing tanpa suatu pendampingan secara terus menerus. Dampak dari realita ini telah menghasilkan benturan sosial di kalangan pelajar, yang pada gilirannya melahirkan konflik di kalangan siswa. Hal ini sangat mungkin terjadi, karena guru belum dapat memainkan perannya sebagai pendidik, pembimbing, ahli, motivator, mediator dan evaluator yang baik dalam Pendidikan Ilmu Pengetahuan Sosial. Olehnya itu, maka penelitian ini mencoba untuk mengkaji lebih jauh tentang peran guru Ilmu Pengetahuan Sosial pada pembelajaran resolusi konflik yang berbasis pada nilai budaya Pela di Maluku.

\section{METODE PENELITIAN}

Model Pendidikan Resolusi Konflik Berbasis Nilai Budaya Pela (PRK-BNBP) merupakan model pembelajaran yang diasumsikan dapat dimanfaatkan secara luas dalam implementasi Pendidikan Ilmu Pengetahuan Sosial di SMP, dengan tahapan pengembangan yang dilakukan secara sistematis dan terkontrol sehingga dapat membuktikan asumsi yang dikemukakan dalam model PRK-BNBP. Untuk mengembangkan pembelajaran ini, peneliti menggunakan jenis penelitian dan pengembangan (Research and Development). Prosedur yang digunakan dalam penelitian ini secara umum merujukan pada prosedur penelitian dan pengembangan yang dikembangkan oleh Borg \& Gall, (2003: 570-571) yang terdiri dari 10 tahapan yakni: (1) melakukan studi pendahuluan, (2) membuat perencanaan, (3) mengembangkan produk awal, (4) melakukan uji lapangan awal, (5) merevisi produk utama, (6) melakukan uji lapangan utama, (7) merevisi produk operasional, (8) melakukan uji operasional, (9) merevisi produk akhir, dan (10) implementasi dan Penyebarluasan. Untuk mempermudah peneliti dalam melakukan penelitian dan pengembangan model PRKBNBP, maka peneliti mengadaptasi asumsi yang dikemukakan oleh Sukmadinata (2007) yang menyatakan bahwa bahwa: "Untuk 
mempermudah peneliti dalam pengembangan model, maka tahapan pengembangan dapat dikelompokkan ke dalam tiga bagian utama penelitian, yakni: (1) tahapan prasurvey/pendahuluan, (2) tahapan pengembangan, dan (3) tahapan pengujian/validasi".

\section{HASIL DAN PEMBAHASAN}

Implementasi Pembelajaran Resolusi Konflik Berbasis Nilai Budaya Pela terdapat empat tema yang dikembangkan dalam pembelajaran PRK-BNBP yang terintegrasi dalam Pendidikan Ilmu Pengetahuan Sosial, yakni: (1) masuknya imperialisme dan kolonialisme barat di Indonesia, (2) mengidentifikasi perkembangan kebijakan dan tindakan pemerintah kolonial, (3) pengaruh yang ditimbulkan oleh kebijakankebijakan pemerintah kolonial di berbagai daerah, dan (4) mendeskripsikan bentukbentuk perlawanan rakyat dalam menentang kolonialisme barat di berbagai daerah. Untuk mengetahui peran guru dan siswa pada pembelajaran di kelas, maka pada penulisan ini, penulis menggunakan satu tema yakni masuknya imperialisme dan kolonialisme barat di Indonesia dengan kompetensi resulusi konflik yakni memahami hakikat konflik. Secara keseluruhan, implementasi tema satu digambarkan sebagai berikut:

Tabel 1

Implementasi Tema

\begin{tabular}{|l|l|}
\hline \multicolumn{2}{|c|}{ Pertemuan Pertama } \\
\hline \multicolumn{1}{|c|}{ Tema 1: } & \multicolumn{1}{|c|}{$\begin{array}{c}\text { Resolusi Konflik } \\
\text { yang dikembangkan: }\end{array}$} \\
\hline $\begin{array}{l}\text { Masuknya Imperialism } \\
\text { dan Kolonialisme Barat } \\
\text { di Indonesia }\end{array}$ & $\begin{array}{l}\text { Memahami Hakikat } \\
\text { Konflik }\end{array}$ \\
\hline
\end{tabular}

Guru memulai tema satu dengan memasuki ruangan kelas tepat pada jam mata pelajaran Ilmu Pengetahuan Sosial dengan alokasi waktu $2 \times 45$ menit. Ketika berada di dalam kelas, guru memberikan salam, memeriksa kehadiran siswa, mengatur kerapian kelas, memotivasis siswa agar dapat mengikuti materi pembelajaran dengan baik, serta mengarahkan siswa mengenai materi yang akan disampaikan dalam pembelajaran Ilmu Pengetahuan Sosial yang memiliki keterkaitan dengan

nilai-nilai budaya Pela dalam kehidupan siswa, dan kelak dapat dijadikan sebagai resolusi konflik. Pada fase ini, guru harus menimbulkan semangat dan rasa ingin tahu siswa tentang materi yang akan disampaikan. Guru memulai fase ini dengan menanyakan nama siswa, berasal dari negeri/desa mana, kemudian guru menjelaskan keterkaitan antara siswa satu dengan siswa yang lain, jika dilihat dari marga dan asal daerah yang dimiliki oleh setiap siswa.

Guru juga memberikan contoh keterkaitan antara satu negeri (desa) dengan negeri yang lain yang terbangun sampai dengan sekarang ini dalam ikatan Pela. Untuk membangkitkan semangat siswa dalam pembelajaran ini, guru memulai dengan mengajak siswa secara bersama-sama menyayikan lagu yang menggambarkan kehidupan Pela dalam masyarakat Maluku.

\section{Judul Lagu: Gandong \\ Gandong, la mari gandong Mari jua ale o \\ Beta mau bilang ale \\ Katong dua satu gandong \\ Hidup ade deng kaka \\ Sungguh manis lawang $e$ Ale rasa beta rasa \\ Katong dua satu gandong.}

\author{
Reff \\ Gandong e sio gandong e \\ Mari beta gendong, beta gendong ale jua, \\ Katong dua cuma satu gandong e \\ Satu hati satu jantong e
}

Tahapan pendahuluan ini bertujuan untuk menumbuhkan nilai-nilai sosial, religius, hukum yang di dalamnya terdapat nilai-nilai kebersamaan, gotong royong, toleransi, kepatuhan, saling mencintai, keadilan dan perdamaian sehingga nilai-nilai tersebut dapat dijadikan rujukan oleh siswa dalam menyelesaikan konflik yang terjadi dalam kehidupan bermayarakat. Setelah tahapan pendahuluan, guru memulai dengan menyampaikan tujuan pembelajaran yang akan dicapai bersama dalam pembelajaran.

Setelah menyampaikan tujuan pembelajaran, guru menanyakan apakah siswa pernah 
mengalami konflik dalam kehidupan seharihari? Konflik apa saja yang pernah dialami oleh siswa? Apa saja akibat yang ditimbulkan dari konflik tersebut? dan bagaimana cara siswa menyelesaikan konflik yang terjadi? Untuk membantu siswa merekonstruksi konflik yang terjadi, guru membagikan siswa kedalam lima kelompok kooperatif (Kelompok Belanda, Portugis, Spanyol, Inggris dan Jepang) yang terdiri dari lima sampai enam orang siswa, kemudian guru meminta siswa untuk mempelajari dan melalukan pencarian informasi secara lengkap mengenai materi kedatangan bangsa barat di Indonesia.

Pengumpulan data dilakukan dalam bentuk menganalisis buku pegangan siswa, bahan ajar 1 pendidikan resolusi konflik, melakukan browsing pada internet. Penemuan informasi ini merujuk pada beberapa pertanyaan yakni: Konflik apa saja yang dapat Anda temui dari materi masuknya bangsa barat ke Indonesia? Apa itu konflik? Apa saja dampak yang ditimbulkan dari kedatangan bangsa barat ke Indonesia? Setelah proses penemuan (inkuiri) selesai dilakukan, guru meminta siswa untuk melalukan analisis, berdiskusi dalam kelompok tentang masalah yang telah dikaji secara bersama-sama. Pada posisi ini, guru berperan sebagai ahli, pembimbing dan mediator dalam pembelajaran. Diskusi kelompok selesai ketika guru meminta kesediaan masing-masing kelompok untuk mempresentasikan hasil diskusi kelompok di depan kelas. Presentasi pertama guru berikan kepada kelompok Belanda, setelah kelompok Belanda selesai memperesntasikan hasil, guru memberikan kesempatan kepada siswa kepada masingmasing kelompok memberikan tanggapan terhadap materi yang dipresentasikan oleh kelompok Belanda. Proses ini berjalan terus, sampai masing-masing kelompok memperoleh bagian untuk mempresentasikan hasil kerja.

Untuk mengembangkan kompetensi resolusi konflik siswa pada tema satu, guru membagikan lembar kerja siswa (LKS). LKS pertama bertujuan untuk mengembangkan kemampuan berpikir kritis siswa tentang hakikat konflik yang merujuk pada beberapa pertanyaan, yakni: (1) Konflik apa saja yang pernah Anda temui di sekolah, (2) Dari konflik di atas, menurut Anda apa itu konflik, (3) Mengapa konflik tersebut terjadi, dan (4) Apa saja dampak dari konflik tersebut? Sedangkan pada LKS kedua, terdapat deskripsi masalah konflik yang telah dikembangkan oleh guru dalam bentuk dialog antara beberapa siswa terkait dengan pemilihan ketua OSIS pada SMPN 1 Kartini. Kemudian guru meminta siswa yang sementara duduk dalam posisi berkelompok membaca dialog konflik secara berulang-ulang dalam kelompok dan menentukan: (1) Apakah negosiasi dan mediasi dapat terlihat dari cerita pendek di atas? (2) Bagaimana bentuk negosiasi yang Anda tawarkan dari cerita di atas? (3) Coba Anda kemukakan pilihan penyelesaian masalah [resolusi konflik] yang sama-sama menguntungkan [win-win problem solving] dari cerita di atas.

Setelah proses diskusi selesai, guru meminta siswa untuk memperesentasikan temuan di depan kelas dengan berpatokan pada lembar kerja siswa yang telah dikembangkan. Untuk membangkitkan ketertarikan siswa terhadap materi pembelajaran yang telah dipresentasikan, guru memodifikasi model pembelajaran Numbered Head Together (NHT). Guru membagikan nomor urut kepada masingmasing siswa. Nomor urut yang digunakan disesuaikan dengan nomor urut absensi kelas. Dalam hal ini guru telah menyiapkan beberapa pertanyaan yang dibuat oleh guru berdasarkan materi pembelajaran yang baru selesai dipresentasikan. Guru memulainya dengan memanggil nomor urut secara acak tanpa harus melihat absensi, dan nomor urut yang dipanggil oleh guru diwajibkan maju ke depan kelas kemudian guru membacakan pertanyaan dan dijawab oleh siswa. Jika ditemukan siswa tersebut belum dapat menjawab pertanyaan tersebut dengan baik, guru memanggil nomor urut yang lain untuk membantu siswa yang belum dapat menjawab pertanyaan yang disampaikan oleh guru. Cara ini dilakukan oleh guru selama berulang-ulang, sampai guru memastikan bahwa materi 1 pembelajaran resolusi konflik dengan tema "memahami hakikat konflik" dapat dipahami dengan baik oleh semua siswa.

Selain NHT, guru juga menggunakan brainstorming dengan cara melontarkan suatu 
masalah ke kelas oleh guru, kemudian siswa menjawab atau menyatakan pendapat, atau komentar sehingga mungkin masalah tersebut berkembang menjadi masalah baru, atau dapat diartikan pula sebagai satu cara untuk mendapatkan banyak ide dari sekelompok siswa dalam waktu yang singkat. Untuk mencegah terjadinya miskonsepsi terhadap materi yang disampaikan, guru mengarahkan dan menanyakan kembali mengenai materi apa saya yang belum dipahami oleh siswa, guru memberikan penguatan terhadap materi yang disampaikan dan memberikan kesempatan kepada siswa untuk mengambil sikap. Sikap yang diharapkan guru dalam pembelajaran ini adalah bagaimana siswa bersikap jika dihadapkan dengan masalah yang didasarkan pada pengetahuan yang dimiliki oleh siswa tersebut. Hal ini merupakan keputusan penting yang dibuat oleh siswa, sehingga kelak masingmasing siswa dapat mengambil keputusan berdasarkan pertimbangan nilai yang berkembang dalam kehidupan siswa sehari-hari. Mengakhiri pertemuan pertama, guru membantu siswa menarik kesimpulan terkait dengan materi yang telah disampaikan, melakukan refleksi akhir yang didasarkan pada nilai budaya Pela dan menutup pembelajaran pertama.

\section{Implementasi Peran Guru dalam Pembelajaran Resolusi Konflik}

Guru dalam pembelajaran memiliki peran yang sangat penting oleh karena itu guru dituntut mengembangkan prinsip belajar sepanjang hayat seirama dengan pengetahuan yang mereka perlukan untuk mendukung pekerjaannya serta menghadapi tantangan dan kemajuan sains dan teknologi, (Mudri 2010). Guru tidak diharuskan memiliki semua pengetahuan, tetapi hendaknya memiliki pengetahuan terhadap materi yang disampaikan, sehingga implementasi pembelajaran di kelas dapat berjalan dengan baik. Di samping penguasaan materi, guru juga dituntut memiliki keragaman model atau strategi pembelajaran, karena tidak ada satu model pembelajaran yang dapat digunakan untuk mencapai tujuan belajar dari topik-topik yang beragam. Mulyasa (2005:137) mendefinisikan sedikitnya 19 peran guru, yakni guru sebagai pendidik, pengajar, pembimbing, pelatih, penasehat, pembaharu (innovator), model dan teladan, pribadi, peneliti, pendorong kreativitas, pembangkit pandangan, pekerja rutin, pemindah kemah, pembawa ceritera, aktor, emansipator, evaluator, pengawet, dan sebagai kulminator. Berdasarkan 19 peran guru di atas, terdapat 6 peran guru dalam pembelajaran yang memiliki relevansi langsung dengan proses pembelajaran pendidikan resolusi konflik berbasis nilai budaya Pela di antaranya:

\section{Guru Sebagai Pendidik}

Guru adalah pendidik, yang menjadi tokoh, panutan, dan identifikasi bagi para peserta didik, dan lingkungannya. Oleh karena itu, guru harus memiliki standar kualitas pribadi tertentu, yang mencakup tanggung jawah, wibawa, mandiri, dan disiplin. Berkaitan dengan tanggung jawab; guru harus mengetahui, serta memahami nilai, norma moral, dan sosial, serta berusaha berperilaku dan berbuat sesuai dengan nilai dan norma tersebut. Guru juga harus bertanggung jawab terhadap segala tindakannya dalam pembelajaran di sekolah, dan dalam kehidupan bermasyarakat. Berkenaan dengan wibawa; guru harus memiliki kelebihan dalam merealisasikan nilai spiritual, emosional, moral, sosial, dan intelektual dalam pribadinya, serta memiliki kelebihan dalam pemahaman ilmu pengetahuan, teknologi, dan seni sesuai dengan bidang yang dikembangkan. Ketika guru mampu memainkan perannya sebagai pendidik, maka kompetensi resolusi konflik akan semakin mudah diimplementasikan dalam pembelajaran. Guru yang memiliki nilai integritas spiritual, sosial, emosional, moral dan intelektual akan menghasilkan pembelajaran resolusi konflik yang baik dan dapat ditiru oleh siswanya.

\section{Guru Sebagai expert}

Membangun resolusi konflik dalam pembelajaran IPS dimulai dengan menemukan sumber-sumber konflik dalam materi pembelajaran IPS. Untuk menganalisis sumber konflik dalam pembelajaran IPS, maka dalam implementasi dibutuhkan guru yang expert di bidangnya. Guru yang expert dalam implementasi pembelajaran, memiliki cirri-ciri sebagai 
berikut; 1) memiliki pemahaman yang mendalam tentang materi pembelajaran; 2) mampu menemukan sumber-sumber konflik dalam materi pembelajaran; 3) memahami eskalasi konflik; 4) mampu mengendalikan rasa marah; 5) dapat mengambil keputusan; dan 6) dapat menyelesaikan konflik secara konstruktif. Mengingat peran guru sebagai expert sangatlah penting dalam pembelajaran resolusi konflik, maka sebelum dilakukan pembelajaran resolusi konflik berbasis nilai budaya "Pela", maka guru dilatih sehingga mampu mengembangkan pembelajaran dengan baik serta dapat menghasilkan kelas yang cinta damai.

\section{Guru Sebagai Pembimbing}

Tugas guru adalah membimbing agar siswa tumbuh dan berkembang sesuai dengan potensi, minat dan bakatnya. Jadi, inti dari peran guru sebagai pembimbing adalah terletak pada kekuatan intensitas hubungan interpersonal antara guru dengan siswa yang dibimbingnya. Untuk dapat membangun kelas yang damai dan menghindari kecemburuan antara sesama siswa dalam pembelajaran, maka guru IPS dalam implementasi pembelajaran resolusi konflik harus dapat mendekatkan diri secara personal kepada siswa. Dengan mengoptimalkan peran guru sebagai pembimbing, siswa dapat mengembangkan resolusi konflik yang baik di antara siswa. Berkaitan dengan itu, maka guru dalam implementasi pembelajaran diharapkan dapat:

1. Memiliki pemahaman tentang anak yang sedang dibimbingnya. Misalnya pemahaman tentang gaya dan kebiasaan belajar serta pemahaman tentang potensi konflik dan bakat yang dimiliki anak dalam menyelesaikan konflik.

2. Guru dapat memperlakukan siswa sebagai individu yang unik dan memberikan kesempatan kepada siswa untuk belajar sesuai dengan keunikan yang dimilikinya, sehingga potensi yang dimiliki oleh siswa dapat dikembangkan dengan baik.

3. Guru seyogyanya dapat menjalin hubungan yang akrab, penuh kehangatan dan saling percaya, termasuk di dalamnya berusaha menjaga kerahasiaan data siswa yang dibimbingnya, apabila data itu bersifat pribadi.

4. Guru senantiasa memberikan kesempatan kepada siswanya untuk mengkonsultasikan berbagai kesulitan yang dihadapi siswanya, baik ketika sedang berada di kelas maupun di luar kelas.

\section{Guru Sebagai Manager}

Sebagai manager guru berkewajiban memonitor hasil belajar para siswa dan masalahmasalah yang dihadapi mereka, memonitor disiplin kelas dan hubungan interpersonal, dan memonitor ketepatan penggunaan waktu dalam menyelesaikan tugas. Dengan bertindak sebagai manager, maka guru dapat meminimalisir berkembangnya konflik dalam diri setiap siswa.

\section{Guru Sebagai Mediator}

Sebagai mediator, memegang peranan yang sangat penting dalam implementasi pembelajaran di kelas. Sebagai mediator, guru dituntut untuk dapat memandu menyelesaikan masalah antar siswa atau kelompok, memandu siswa memformulasikan pertanyaan atau mengkonstruksi suatu masalah, memandu siswa mengaitkan informasi baru dengan pengetahuan awal yang dimiliki, memandu para siswa mengembangkan sikap positif, membantu siswa memahami eskalasi konflik, membantu siswa mengendalikan rasa marah, membantu siswa membuat keputusan, dan membantu siswa menghembangkan resolusi konflik yang baik. Dampak dari peran guru sebagai mediator adalah diharapkan siswa dapat mengimplementasikan hal yang sama, seperti yang telah dimodelkan oleh guru dalam menyelesaikan konflik yang dihadapi baik itu di sekolah, maupun di dalam masyarakat.

\section{Guru Sebagai Evaluator}

Evaluasi atau penilaian merupakan aspek pembelajaran yang paling kompleks, karena melibatkan banyak latar belakang dan hubungan, serta variabel lain yang mempunyai arti apabila berhubungan dengan konteks yang hampir tidak mungkin dapat dipisahkan dengan setiap segi penilaian. Tidak ada pembelajaran tanpa penilaian, karena penilaian merupakan 
proses menetapkan kualitas hasil belajar, atau proses untuk menentukan tingkat pencapaian tujuan pembelajaran oleh peserta didik. Dalam pembelajaran resolusi konflik, penilaian dilaksanakan dengan prinsip-prinsip dan dengan teknik yang sesuai, mungkin tes atau nontes. Teknik apapun yang dipilih, penilaian harus dilakukan dengan prosedur yang jelas, yang meliputi tiga tahap, yaitu persiapan, pelaksanaan, dan tindak lanjut. Evaluasi dalam pembelajaran resolusi konflik dilakukan pada dua bagian terpisah yakni pada saat proses pembelajaran untuk menilai aspek sikap dan keterampilan siswa dan tahapan akhir pembelajaran. Tahapan akhir proses pembelajaran untuk menganalisis kompetensi resolusi konflik siswa aspek pengetahuan siswa.

Untuk lebih jelas peran guru IPS dalam pembelajaran resolusi konflik berbasis nilai budaya pela, terlihat pada gambar di bawah ini:

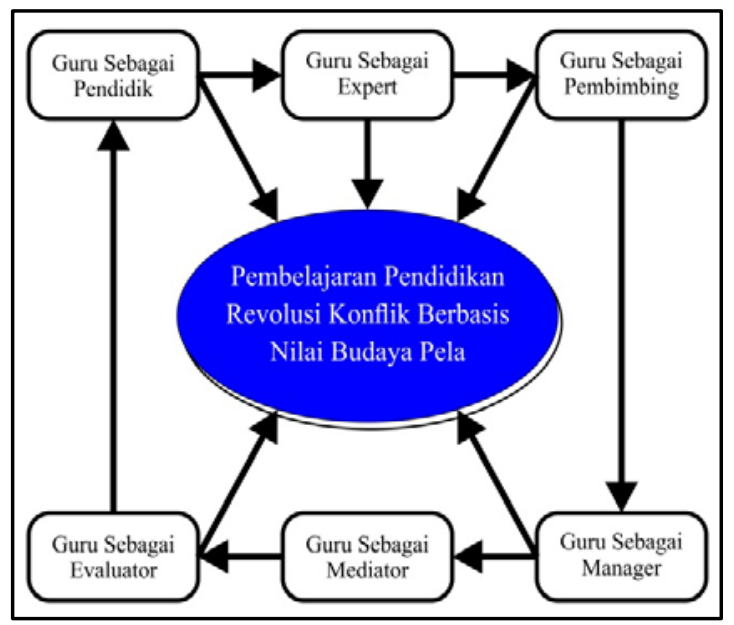

Gambar 1 Peran Guru IPS Dalam Pembelajaran PRK-BNBP

Peranan guru dalam PRK-BNBP yang terlihat pada gambar di atas, dalam implementasi- nya bersifat situsional, kondisional dan fungsional sehingga peran guru tidaklah kaku dalam tataran implementasi. Guru dapat bertindak sebagai seorang manager, atau evaluator pada awal pembelajaran, tergantung dari tujuan yang ingin dicapai guru dalam pembelajaran. Karakteristik belajar yang dikembangkan oleh guru dalam implementasi PRK-BNBP adalah pembelajaran yang dapat membelajarkan siswa secara aktif sesuai dengan potensi dan perkembangan siswa. Hal ini berati bahwa guru harus dapat mendesain, mengimplementasikan dan mengevaluasi pembelajaran berkadar aktivitas siswa.

Untuk sampai ke arah itu, maka guru harus mengembangkan tujuh komponen dalam belajar yani: (1) mendesain pembelajaran Ilmu Pengetahuan Sosial yang bersumber pada nilai budaya "Pela" yang dapat dijadikan rujukan sebagai resolusi konflik, (2) memotivasi siswa dalam belajar, (3) mengelola kelas sehingga menghasilkan aktivitas belajar yang menyenangkan, (4) menciptakan kelas yang damain, (5) memilih dan mengunakan strategi belajar yang dapat mengembangkan kreatifitas siswa, (6) memilih dan menerapkan media dan sumber belajar yang dapat membantu siswa merekonstruksi suatu masalah, dan (7) melakukan penilaian secara komprehensif maupun spesifik sesuai kebutuhan sisitem penilaian. Dengan kemampuan tersebut, guru akan dapat mengembangkan pembelajaran PRK-BNBP yang berpihak pada siswa aktif secara maksimal.

Ritiauw (2017: 364) Secara operasional kegiatan guru dan siswa selama proses pembelajaran dapat dijabarkan sebagai berikut:

Tabel 2 Peran Guru dalam Tahapan Pembelajaran Resolusi Konflik

\begin{tabular}{|c|l|l|l|}
\hline \multirow{2}{*}{ No } & $\begin{array}{c}\text { Tahapan } \\
\text { Pembelajaran }\end{array}$ & \multicolumn{1}{|c|}{ Kegiatan Guru } & \multicolumn{1}{c|}{ Kegiatan Siswa } \\
\hline 1 & Pendahuluan & $\begin{array}{l}\text { Memeriksa kehadiran siswa, kebersihan } \\
\text { dan kerapihan kelas. }\end{array}$ & $\begin{array}{l}\text { Siswa memperhatikan, mencermati, } \\
\text { dan melaksanakan penjelasan guru. }\end{array}$ \\
& & $\begin{array}{l}\text { Memberikan motivasi kepada siswa agar } \\
\text { siap dalam mengikuti pembelajaran. }\end{array}$ & \\
& & $\begin{array}{l}\text { Mengembangkan scaffolding yang } \\
\text { berbasis pada nilai budaya Pela. }\end{array}$ & \\
& & Guru menjelaskan tujuan pembelajaran. & \\
\hline
\end{tabular}




\begin{tabular}{|c|c|c|c|}
\hline No & $\begin{array}{c}\text { Tahapan } \\
\text { Pembelajaran }\end{array}$ & Kegiatan Guru & Kegiatan Siswa \\
\hline \multirow[t]{2}{*}{2} & \multirow[t]{2}{*}{$\begin{array}{l}\text { Mengenalkan } \\
\text { konflik }\end{array}$} & $\begin{array}{l}\text { Mengembangkan pengetahuan, sikap } \\
\text { dan keterampilan awal siswa melalui } \\
\text { tanya jawab. } \\
\text { 1. Apakah anda pernah mengalami } \\
\text { konflik? } \\
\text { 2. Berikan contoh konflik di } \\
\text { sekolah/rumah/masyarakat. } \\
\text { 3. Apa itu konflik? } \\
\text { 4. Mengapa konflik dapat berkembang } \\
\text { menjadi lebih besar? }\end{array}$ & $\begin{array}{l}\text { Diskusi kelas secara keseluruhan } \\
\text { tentang materi yang dikembangkan. }\end{array}$ \\
\hline & & $\begin{array}{l}\text { Membimbing siswa melakukan } \\
\text { klarifikasi konsep dan nilai, khususnya } \\
\text { yang berkaitan dengan konflik yang } \\
\text { ditemukan. }\end{array}$ & $\begin{array}{l}\text { Melakukan klarifikasi konsep dan nilai } \\
\text { yang berkembang dalam konflik. }\end{array}$ \\
\hline \multirow[t]{4}{*}{3} & \multirow[t]{4}{*}{$\begin{array}{l}\text { Mengumpulkan } \\
\text { Fakta-Fakta } \\
\text { Konflik }\end{array}$} & $\begin{array}{l}\text { Guru membentuk kelompok yang } \\
\text { terdiri dari } 4-5 \text { orang. Membagikan } \\
\text { lembar kerja siswa dan menjelaskan } \\
\text { tugas kelompok. }\end{array}$ & $\begin{array}{l}\text { Membentuk kelompok kooperatif } \\
\text { dalam pembelajaran. }\end{array}$ \\
\hline & & $\begin{array}{l}\text { Membimbing siswa secara bertahap } \\
\text { untuk mengidentifikasi masalah. }\end{array}$ & $\begin{array}{l}\text { Berusaha mengidentifikasi } \\
\text { permasalahan dengan menggunakan } \\
\text { parameter yang jelas. }\end{array}$ \\
\hline & & $\begin{array}{l}\text { Membimbing siswa melakukan } \\
\text { pencarian informasi dengan berbagai } \\
\text { cara dan informasi. }\end{array}$ & $\begin{array}{l}\text { Melakukan pencarian informasi dengan } \\
\text { berbagai cara serta dengan } \\
\text { menggunakan kecerdasan majemuk } \\
\text { yang dimiliki. }\end{array}$ \\
\hline & & $\begin{array}{l}\text { Membimbing siswa melakukan } \\
\text { pengelolaan informasi. }\end{array}$ & $\begin{array}{l}\text { Melakukan pengelolaan pengaturan } \\
\text { informasi (information managemant) yang } \\
\text { telah diperoleh, dengan berpatokan } \\
\text { pada: } \\
\text { a. Know, yaitu informasi apa yang } \\
\text { diketahui. } \\
\text { b. Need to know, yaitu informasi apa } \\
\text { yang dibutuhkan. } \\
\text { c. Need to do, apa yang akan } \\
\text { dibutuhkan dengan informasi yang } \\
\text { ada. }\end{array}$ \\
\hline \multirow[t]{4}{*}{4} & \multirow[t]{4}{*}{$\begin{array}{l}\text { Negosiasi dalam } \\
\text { Konflik }\end{array}$} & $\begin{array}{l}\text { Guru membimbing dan mengawasi } \\
\text { jalannya diskusi }\end{array}$ & Presentasi kelompok kooperatif. \\
\hline & & $\begin{array}{l}\text { Membimbing siswa melakukan } \\
\text { negosiasi berdasarkan masalah yang } \\
\text { diperoleh dalam kelompok. }\end{array}$ & $\begin{array}{l}\text { Melakukan negosiasi berdasarkan } \\
\text { masalah yang diperoleh dalam } \\
\text { kelompok. }\end{array}$ \\
\hline & & $\begin{array}{l}\text { Membimbing peserta didik dalam } \\
\text { mencetuskan ide-ide, konsep, dan } \\
\text { alternatif yang dimiliki untuk } \\
\text { memecahkan konflik. }\end{array}$ & $\begin{array}{l}\text { Menemukan ide-ide, konsep, dan } \\
\text { alternatif yang dimiliki untuk } \\
\text { memecahkan konflik. }\end{array}$ \\
\hline & & $\begin{array}{l}\text { Membimbing siswa mengambil } \\
\text { keputusan untuk memilih suatu } \\
\text { alternatif pemecahan masalah yang } \\
\text { paling tepat. }\end{array}$ & $\begin{array}{l}\text { Memutuskan, memilih satu alternatif } \\
\text { pemecahan masalah yang paling tepat. }\end{array}$ \\
\hline
\end{tabular}




\begin{tabular}{|c|l|l|l|}
\hline No & $\begin{array}{c}\text { Tahapan } \\
\text { Pembelajaran }\end{array}$ & \multicolumn{1}{|c|}{ Kegiatan Guru } & \multicolumn{1}{c|}{ Kegiatan Siswa } \\
\hline 5 & $\begin{array}{l}\text { Resolusi } \\
\text { Konflik }\end{array}$ & $\begin{array}{l}\text { Membimbing peserta didik menentukan } \\
\text { sikap dan keterampilan berdasarkan } \\
\text { pengetahuan yang diperoleh. }\end{array}$ & $\begin{array}{l}\text { Peserta didik diberikan kesempatan } \\
\text { yang leluasa untuk menentukan sikap } \\
\text { dan keterampilan berdasarkan } \\
\text { pengetahuan yang diperoleh. }\end{array}$ \\
\cline { 3 - 4 } & $\begin{array}{l}\text { Membimbing dan mengawasi peserta } \\
\text { didik dalam melakukan perumusan atau } \\
\text { pengambilan keputusan terhadap } \\
\text { konflik yang telah dinegosiasikan. }\end{array}$ & $\begin{array}{l}\text { Mengambil keputusan terhadap konflik } \\
\text { yang telah dinegosiasikan, baik dalam } \\
\text { kelompok maupun secara klasikal. }\end{array}$ \\
\cline { 3 - 5 } & $\begin{array}{l}\text { Membimbing siswa merumuskan } \\
\text { kesimpulan dari konflik serta } \\
\text { mengaitkan dengan nilai budaya pela } \\
\text { yang dikembangkan dalam } \\
\text { pembelajaran. }\end{array}$ & $\begin{array}{l}\text { Merumuskan kesimpulan akhir } \\
\text { pembelajaran yang berbasis pada nilai } \\
\text { budaya "pela". }\end{array}$ \\
\hline
\end{tabular}

Implementasi peran guru seperti yang terlihat pada Tabel $1 \mathrm{di}$ atas memiliki 5 tahapan yang harus dikembangkan guru dalam pembelajaran resolusi konflik berbasis nilai budaya Pela. Kelima tahapan ini dalam implementasinya, memiliki keterkaitan yang sangat erat, sehingga diharapkan oleh guru Ilmu Pengetahuan Sosial, sebelum berpindah pada tahapan selanjutnya, siswa minimal sudah mulai memiliki pengetahuan awal tentang konflik yang akan dikembangkan dalam pembelajaran, sehingga pengetahuan awal yang dimiliki oleh siswa ini kelak dapat dijadikan sebagai salah satu sumber resolusi konflik dalam pembelajaran Ilmu Pengetahuan Sosial di kelas.

\section{Pembahasan}

Pembelajaran adalah proses interaksi peserta didik dengan pendidik dan sumber belajar pada suatu lingkungan belajar. Pembelajaran merupakan bantuan yang diberikan pendidik agar dapat terjadi proses pemerolehan ilmu dan pengetahuan, penguasaan kemahiran dan tabiat, serta pembentukan sikap dan kepercayaan pada peserta didik. Dengan kata lain, pembelajaran adalah proses untuk membantu peserta didik agar dapat belajar dengan baik (Pace, 2012: 329-358). Lebih lanjut Sagala (2011: 61) menyatakan bahwa pembelajaran adalah suatu proses di mana lingkungan seseorang secara disengaja dikelola untuk memungkinkan ia turut serta dalam tingkah laku tertentu dalam kondisi-kondisi khusus atau menghasilkan respons terhadap situasi tertentu, pembelajaran merupakan subset khusus dari pendidikan. Mengatur, merencanakan dan mengimplementasikan pembelajaran pendidikan resolusi konflik di kelas merupakan tugas dan tanggung jawab yang dimiliki oleh guru sebagai sosok yang paling bertanggungjawab dalam membentuk generasi bangsa yang cinta akan perdamaian.

Untuk menghasilkan peserta didik yang cinta damai maka guru harus mampu menjadi model dan mediator konflik dalam pembelajaran. Dengan demikian, maka pembelajaran Ilmu Pengetahuan Sosial harus dapat dikembangkan dengan baik secara efektif dan efisien dengan harapan dapat menghasilkan peserta didik yang peka terhadap fenomena konflik yang terjadi dalam kehidupan masyarakat, (Fisher et al, 2001: 96; Webel dan Galtung 2007: 56). Hal ini sejalan dengan semangat Pendidikan Ilmu Pengetahuan Sosial, yakni pengembangan kompetensi peserta didik agar peka terhadap masalah sosial seperti konflik yang terjadi di masyarakat, memiliki sikap positif untuk menyikapi masalah yang terjadi serta memiliki keterampilan dalam mengatasi setiap masalah baik yang menimpa dirinya sendiri maupun di masyarakat. Tujuan tersebut dapat dicapai mana kala program-program pelajaran Ilmu Pengetahuan Sosial di sekolah diorganisasikan secara baik oleh guru sebagai administrator dalam pembelajaran di kelas.

Kizilirmak (2016: 6) menyatakan bahwa proses pembelajaran harus menekankan kepada kemampuan dan keterampilan peserta didik 
dalam menyikapi dan memecahkan serta mengambil tindakan terhadap berbagai fenomena konflik dan masalah-masalah sosial budaya yang terjadi di lingkungan masyarakatnya (lokal, regional, nasional, dan internasional) dengan bersandar pada nilai-nilai sosial dan budaya masyarakat dimana mereka hidup dan berkembang.

Berkaitan dengan pikiran di atas, maka pemanfaatan masalah-masalah sosial oleh guru sebagai sumber dalam pembelajaran Ilmu Pengetahuan Sosial sangat penting, dan lingkungan menyediakan sumber pembelajaran Ilmu Pengetahuan Sosial yang sangat kaya dengan pengetahuan dan pengalaman siswa itu sendiri.

Pada implemetasi model PRK-BNBP fungsi guru sebagai seorang mediator adalah: (1) merancang terjadinya diskusi/pertemuan kelompok, (2) memimpin jalannya diskusi kelompok atau rapat, (3) memelihara atau menjaga aturan yang telah disepakati dalam dikusi kelompok atau rapat, (4) mengendalikan emosi yang berkembang dalam diskusi, (5) mendorong masing-masing kelompok atau pihak/perunding yang kurang mampu atau segan mengemukakan pandangannya, (6) membantu tiap kelompok/pihak untuk menyusun dan mengusulkan alternatif pemecahan masalah, dan (7) membantu tiap kelompok untuk mengambil keputusan dengan mengutamakan win-win problem solving.

Menurut prinsip konstruktivistik, seorang guru berperan sebagai mediator dan fasilitator berfungsi untuk membantu agar proses belajar siswa berjalan dengan baik. Sukiman (2008: 65) menjelaskan bahwa fungsi mediator dan fasilitator dapat dijabarkan dalam beberapa tugas sebagai berikut:

1. Menyediakan pengalaman belajar yang memungkinkan siswa bertanggungjawab dalam membuat rancangan, proses, dan penelitian

2. Menyediakan atau memberikan kegiatankegiatan yang merangsang keingintahuan siswa dan membantu mereka untuk mengekspresikan gagasan-gagasannya dan mengkomunikasikan ide ilmiah mereka. Guru perlu menyediakan pengalaman konflik, menyediakan sarana yang merangsang siswa untuk berpikir secara produktif, menyediakan kesempatan dan pengalaman yang mendukung proses belajar siswa.

3. Memonitor, mengevaluasi, dan menunjukkan apakah pemikiran siswa jalan atau tidak. Guru menunjukkan dan mempertanyakan apakah pengetahuan siswa itu berlaku untuk menghadapi persoalan yang berkaitan dengan masalah atau tidak, serta guru membantu mengevaluasi keputusan dan kesimpulan akhir siswa dalam implementasi pembelajaran di kelas.

Implementasi model PRK-BNBP dipandang sebagai suatu inovasi baru bagi guru dalam mengembangkan pembelajaran Ilmu Pengetahuan Sosial, yang memungkinkan guru menemukan muatan konflik dalam pembelajaran Ilmu Pengetahuan Sosial dan mengembangkan solusi berdasarkan nilai budaya pela yang berkembang. Dengan penerapan model PRK-BNBP, guru memiliki pengetahuan yang luas tentang model-model pembelajaran terbaru yang berdampak pada pengembangan pembelajaran Ilmu Pengetahuan Sosial di kelas yang berbasis pada nilai budaya Pela sebagai resolusi konflik dalam pembelajaran.

\section{Kesimpulan}

Peran guru dalam pembelajaran di kelas sampai kapanpun tidak akan dapat tergantikan karena guru merupakan maestro tercapainya orkestra yang baik dalam pembelajaran. Peran guru dalam pembelajaran mencakup tiga hal utama yakni perencanaan, implementasi dan evaluasi. Ketiga komponen ini harus dimiliki oleh guru dalam membangun pembelajaran yang lebih berpihak kepada siswa.

Peran guru dalam pembelajaran resolusi konflik yang berbasis pada nilai budaya Pela di Kota Ambon yang terintegrasi dalam pembelajaran Ilmu Pengetahuan Sosial, dikembangkan dengan tujuan agar siswa dapat menyelesaikan konflik baik yang terjadi dalam kehidupan setiap hari siswa baik di sekolah, rumah, tempat bermain dan masyarakat. Untuk mencapai tujuan dimaksud, maka dalam implementasi pembelajaran Ilmu Pengetahuan Sosial, guru diharapkan dapat mengembangkan 
tahapan perencanaan, implementasi dan evaluasi semaksimal mungkin, sehingga guru dapat memainkan perannya sebagai bagian penting dalam membangun kelas yang damai dalam pembelajaran. Sejumlah peran yang mestinya dapat dikembangkan oleh guru dalam pengimplementasian pembelajaran resolusi konflik berbasis nilai budaya Pela di kota Ambon misalnya guru harus berperan sebagai pendidik, expert, pembimbing, manager, mediator dan evaluator.

Keenam peran guru dalam implementasi pembelajaran resolusi konflik berbasis nilai budaya Pela lebih bersifat fleksibel dalam implementasi. Ketika guru mampu memainkan perannya seperti yang digambarkan di atas, maka diharapkan pencapaian kompetensi resolusi konflik siswa dapat terbangun dengan baik yang semuanya berdampak pada pencapaian kelas yang damai dalam pembelajaran Ilmu Pengetahuan Sosial di sekolah.

\section{Daftar Pustaka}

Al Muchtar, S. (2004). Pengembangan Berpikir dan Nilai Dalam IPS. Bandung: Gelar Pustaka Mandiri.

Borg, W. R. \& Gall, M. D. (2003). Educational research: an introduction (7thed.). New York: Longman, Inc.

Deborah Loewenberg Ball and Francesca M. Forzan. (2010). The Work of Teaching and the Challenge for Teacher Education. Journal of Teacher Education, 60 (5): 497511.

Fisher, S. ed al. (2001). Mengelola Konflik: Ketrampilan dan Starategi untuk Bertindak,ed. al. S.N Kartikasariet, (Indonesia: Zed Books \& Responding to Conflict (CRCT).

Hamalik, Oemar. (2008). Pendidikan Guru Berdasarkan Pendekatan Kompetensi. Cet. V, Jakarta: Bumi Aksara.

Jones, Deana C. Mrs. (2015). Conflict Resolution for the Classroom, TEACH Journal of Christian Education, 9 (2).

Jones, T.S. (2004). Conflict resolution education: the field, the findings, and the future. Conflict Resolution Quarterly. (Online, 2 November 2018), 22 (1).
Kartadinata Sunaryo. (2012). Restructuring Education Culture. Indonesia University of Education: Bandung.

Kizilirmak, J., Wiegmann, B., \& Klavehn, A. R. (2016). Problem Solving as an Encoding Task: A Special Case of the Generation Effect. Journal of Problem Solving, 9 (2).

Maftuh, B. (2010). Memperkuat Peran IPS dalam Membelajarkan Keterampilan Sosial dan Resolusi Konflik. Pidato Pengukuban Jabatan Guru Besar dalam bidang Pendidikan Ilmu Pengetabuan Sosial Pada Fakultas Pendidikan Ilmu Pengetahuan SosialUniversitas Pendidikan Indonesia.

Michael Scriven. (1994). Duties of The Teacher: Journal of Personnel Evaluation in Education. 8 (2).

Mudri. M. Walid. (2010). Kompetensi dan Peranan Guru Dalam Pembelajaran. Jurnal Falasifa. 1 (1).

Nadine E. Garner. (2008). Conflict Resolution Programs in the Schools. American Counseling Association.

Pace, J. L. (2012). Teaching Literacy through Social Studies under No Child Left Behind. The Journal of Social Studies Research, 36 (4).

Sagala, S. (2011). Konsep dan Makna Pembelajaran. Bandung: Alfabeta.

Said. H. Hasan. (2012). Revitalisasi Pendidikan IPS dan Ilmu Sosial Untuk Pembangunan Bangsa. Ed. Suryadi Karim dan malihah eli. Inovasi pembelajaran IPS. Bandung: Rizqi Press dan FPIPS UPI.

Sapriya. (2012). Pendidikan IPS Konsep Pembelajaran. Bandung: Rosda.

Seyedali Ahrari, at all. (2013). Role of Social Studies for Pre-Service Teachers in Citizenship Education. International Education Studi. 6 (12).

Somantri, M. N. (2001), Menggagas Pembaharuan Pendidikan IPS, Bandung: PT. Remaja Rosda Karya. 
Sukiman. (2008). Teori Pembelajaran dalam Pandangan Konstruktivisme dan Pendidikan Islam. Jurnal Kependidikan Islam, 3 (1).

Sukmadinata. N. S. (2004b). Kurikulum dan Pembelajaran "Kompetensi". Bandung: Yayasan Kesuma.

Webel, C. dan Galtung, J. (2007). Handbook of Peace and Conflict Studies. New York: Routledge.

Welton, D.A. (1987). Social Studies and the Human Experience: The Disciplinary Foundations In UNICEF (1987) Children and Their World, Geneva: UNICEF.

Bodine, R. J., and Crawford, D. K. (1994a). Creating the Peaceable School, Comprehensive Program for Teaching Conflict Resolution: Program Guide. Champaign, Illinois: Research Press.
Sukmadinata, N. S. (2007a). Metode Penelitian Pendidikan. Bandung. Remaja Rosdakarya.

Mulyasa. E. (2008). Menjadi Guru Profesional, Menciptakan Pembelajaran Kreatif dan Menyenangkan. Cet. VII; Bandung: Remaja Rosda Karya.

Ritiauw Samuel Patra, Maftuh B, Malihah E. (2017). The Development of Desing Model of Conflict Resolution Education Based On Cultural Values of Pale. Cakrawala Pendidikan. XXXVI, (3).

Ritiauw Samuel Patra, Maftuh B, Malihah E. (2018). Model of Conflict Resolution Education Based On Cultural Value of Pela in Social Studies Learning. 1 st International on Social studiess Education (ICSSE 2017). Atlantis Press. 